\title{
Consciousness-Raising: A Tool for Feminist Praxis in Research and Granting Voice
}

\author{
Joanne Ardovini ${ }^{1}$
}

There is a long standing debate within the Social Sciences between mainstream/traditional researcher and feminist researcher. Both challenge each other's theories, methodologies, and methods. The mainstream ideologies are built upon the methodological assumptions of positivism. While, feminist ideologies challenge these assumptions and are subjective in nature. This shift allows for less restrictive, more creative, and more inclusive research to occur. Examples of such innovative tools for collecting data include: consciousnessraising, group diaries, dramas, genealogies, network tracing, nonauthoritative research voices, and stream-of-consciousness narratives. These methods grant voice to those whom have been silenced by traditional research by exploring the experiences of those marginalized within our society in their own words. By granting them a voice, feminist methodologists render a human quality to those we are studying. Our research participants become people with a plethora of experiences and realities crucial to the field of Social Science. Upon hearing the voices that feminist research exposes, we are often confronted with the misogyny of everyday life for many women. This paper discusses consciousness-raising as a specific example of such a research method. Consciousness-raising allows for the inclusion of women and minority experiences while exploring the construction of their realities. The goal is to raise the awareness concerning social inequality of the participants, the researchers, the readers, the educator, and the student. This article discusses this process. Beginning with a brief discussion of a feminist approach to research and education as compared to a traditional approach and ending with a discussion of consciousness-raising as a tool to granting voice. [Article copies available for a fee from The Transformative Studies Institute. E-mail address: journal@transformativestudies.org Website: http://www.transformativestudies.org $\mathbb{C} 2015$ by The Transformative Studies Institute. All rights reserved.]

KEYWORDS: Feminism, Research, Methods, Positivism, Subjectivity, Reflexivity.

\footnotetext{
${ }^{1}$ Joanne Ardovini, Ph.D., is an Associate Professor at Metropolitan College of New York. Dr. Ardovini specializes in Feminist Theory, Methodology, Pedagogy, as well as Social Problems, Deviance, Race and Ethnic Relations, and Criminology. She has been published in the areas of Feminist Pedagogy, Methods, Inequalities in Education, Juvenile Boot Camps, Media Portrayal of Rape, Victimization/Sexual Harassment and innovations in curriculum development. Her book entitled, It is cold and lonely here at the middle: Discrimination against female graduate teaching instructors, discusses the marginalization of women in higher education. She is currently exploring an examination of the effectiveness of faculty evaluation instruments and curriculum development. Address correspondence to: Joanne Ardovini, Metropolitan College of New York, 75 Varick Street, New York, New York 10013-1919; e-mail: JArdovini@MCNY.EDU.
} 